\title{
MEMBANGUN ARGUMEN TENTANG DINAMIKA DAN TANTANGAN PANCASILA SEBAGAI IDEOLOGI NEGARA
}

\author{
YOVANDA DWI PUTRA
}

Yovandaputra54@gmail.com

20220095

STIE AKBP KBP PADANG

\begin{abstract}
A. Pendahuluan
Dinamika Pancasila sebagai ideologi negara dalam sejarah bangsa Indonesia memperlihatkan adanya pasang surut dalam pelaksanaan nilai-nilai Pancasila. Pancasila sebagai ideologi negara dalam masa pemerintahan Presiden Soekarno; sebagaimana diketahui bahwa Soekarno termasuk salah seorang perumus Pancasila, bahkan penggali dan memberi nama untuk dasar negara. Pancasila sebagai ideologi dalam masa pemerintahan Presiden Soeharto diletakkan pada kedudukan yang sangat kuat melalui TAP MPR No. II/1978 tentang pemasyarakatan P-4. Pada masa Soeharto ini pula, ideologi Pancasila menjadi asas tunggal bagi semua organisasi politik (Orpol) dan organisasi masyarakat (Ormas).
\end{abstract}

Bahkan pada masa reformasi masih mengalami pasang surut yakni,enggannya para penyelenggara negara mewacanakan tentang pancasila, bahkan berujung pada hilangnya pancasila dikurikulum nasional. Meskipun pada akhirnya timbul kesadaran penyelenggara negara tentang pendidikan pancasila di perguruan tinggi.

\section{B. Pembahasan}

Unsur-unsur yang mempengaruhi tantangan terhadap pancasila sebagai ideologi negara meliputi faktor eksternal dan internal. Adapun faktor eksternal meliputi hal-hal berikut :

- Pertarungan ideologi antara negara-negara super power antara Amerika Serikat dan Uni Soviet antara 1945 sampai 1990 yang berakhir dengan bubarnya negara Soviet sehingga Amerika menjadi satu-satunya negara super power.

- Menguatnya isu kebudayaan global yang ditandai dengan masuknya berbagai ideologi

- asing dalam kehidupan berbangsa dan bernegara karena keterbukaan informasi.

- Meningkatnya kebutuhan dunia sebagai akibat pertambahan penduduk dan kemajuan

- ideologi sehingga terjadi eksploitasi terhadap sumber daya alam secara matif. Dampak konkritnya adalah kerusakan lingkungan, seperti banjir, kebakaran hutan.

Adapun faktor internal meliputi hal-hal sebagai berikut :

- Pergantian rezim yang berkuasa melahirkan kebijakan politik yang berorientasi pada 
- kepentingan kelompok atau partai sehingga ideologi Pancasila sering terabaikan.

- Penyalahgunaan kekuasaan (korupsi) mengakibatkan rendahnya kepercayaan masyarakat terhadap rezim yang berkuasa sehingga kepercyaan terhadap ideologi menurut drastis.

Penyelenggaraan pendidikan Pancasila sebagai mata kuliah di perguruan tinggi ditegaskan dalam Surat Edaran Direktorat Jenderal Pendidikan Tinggi Nomor 914/E/T/2011, tertanggal 30 Juni 2011, ditentukan bahwa perguruan tinggi harus menyelenggarakan pendidikan Pancasila minimal 2 (dua) SKS atau dilaksanakan bersama mata kuliah pendidikan kewarganegaraan dengan nama pendidikan Pancasila dan kewarganegaraan (PPKn) dengan bobot minimal 3 (tiga) SKS. Selanjutnya, Undang-Undang Republik Indonesia Nomor 12 tahun 2012, tentang pendidikan tinggi, memuat penegasan tentang pentingnya dan ketentuan penyelenggaraan pendidikan Pancasila sebagaimana termaktub dalam pasal-pasal berikut.

- Pasal 2, menyebutkan bahwa pendidikan tinggi berdasarkan Pancasila, Undang-Undang Dasar Negara Republik Indonesia tahun 1945, Negara Kesatuan Republik Indonesia, dan Bhinneka Tunggal Ika.

- Pasal 35 ayat (3) menegaskan ketentuan bahwa kurikulum pendidikan tinggi sebagaimana dimaksud pada ayat (1) wajib memuat mata kuliah: agama, Pancasila, kewarganegaraan, dan bahasa Indonesia.

Dengan demikian, berdasarkan ketentuan dalam pasal 35 ayat (3) Undang-Undang Republik Indonesia Nomor 12 Tahun 2012, tentang pendidikan Tinggi, yang dimaksud dengan mata kuliah pendidikan Pancasila adalah pendidikan untuk memberikan pemahaman dan penghayatan kepada mahasiswa mengenai ideologi bangsa Indonesia. Dengan landasan tersebut, Ditjen Dikti mengembangkan esensi materi pendidikan Pancasila yang meliputi:

1. Pengantar perkuliahan pendidikan Pancasila

2. Pancasila dalam kajian sejarah bangsa Indonesia

3. Pancasila sebagai dasar negara

4. Pancasila sebagai ideologi negara

5. Pancasila sebagai sistem filsafat

6. Pancasila sebagai sistem etika

7. Pancasila sebagai dasar nilai pengembangan ilmu.

Ditegaskan bahwa penyelenggaraan pendidikan Pancasila di perguruan tinggi itu wajib diselenggarakan dan sebaiknya diselenggarakan sebagai mata kuliah yang berdiri sendiri dan 
harus dimuat dalam kurikulum masing-masing perguruan tinggi. Keberadaan mata kuliah pendidikan Pancasila merupakan kehendak negara, bukan kehendak perseorangan atau golongan, demi terwujudnya tujuan negara. Keberadaan mata kuliah Pancasila semakin kokoh dengan berlakunya Undang-Undang Republik Indonesia Nomor 2 Tahun 1989, tentang Sistem Pendidikan Nasional, yang pada pasal 39 ditentukan bahwa kurikulum pendidikan tinggi harus memuat mata kuliah pendidikan Pancasila.

Pasal 1 SK Dirjen Dikti Nomor 467/DIKTI/Kep/1999, yang substansinya menentukan bahwa mata kuliah pendidikan Pancasila adalah mata kuliah yang wajib ditempuh oleh seluruh mahasiswa baik program diploma maupun program sarjana.

\section{Tantangan Pendidikan Pancasila}

Tantangan yang dihadapi dalam proses pembelajaran pendidikan pancasila pada era revolusi saat ini peserta didik yang sudah terlepas dari ponsel pintar, saat ini mereka dengan mudah mendapatkan informasi dari luar melalui internet yang terkadang informasi tersebut tidak sesuai dengan nilai-nilai pancasila. Namun hal tersebut juga dapat diatasi dengan cara memanfaatkan perkembangan informasi serta Ilmu Pengetahuan dan Teknologi (IPTEK) menjadi media dalam penanaman dan penguatan Pancasila di era revolusi. Guru dan dosen dituntut untuk dapat lebih kreatif dalam mengembangkan metode pembelajaran pendidikan Pancasila melalui media pembelajaran, seperti membuat game serta film animasi yang mangajarkan nilai-nilai Pancasila dan sekaligus dapat pula membentuk karakter peserta didik.

Pendekatan pembelajaran yang direkomendasikan dalam mata kuliah pendidikan Pancasila adalah pendekatan pembelajaran yang berpusat kepada mahasiswa (student centered learning), untuk memahami dan menghayati nilai-nilai Pancasila baik sebagai etika, filsafat negara, maupun ideologi bangsa secara scientific. Dalam Undang-Undang Republik Indonesia, Nomor 20 tahun 2003, pasal 3 menegaskan bahwa: pendidikan nasional berfungsi mengembangkan dan membentuk watak serta peradaban bangsa yang bermartabat dalam rangka mencerdaskan kehidupan bangsa, bertujuan untuk berkembangnya potensi peserta didik agar menjadi manusia yang beriman dan bertakwa kepada Tuhan Yang Maha Esa, berakhlak mulia, sehat, berilmu, cakap, kreatif, mandiri, dan menjadi warga negara yang demokratis serta bertanggung jawab.

Dengan demikian, pemahaman nilai-nilai Pancasila di kalangan mahasiswa amat penting, tanpa membedakan pilihan profesinya di masa yang akan datang, baik yang akan berprofesi sebagai pengusaha/entrepreneur, pegawai swasta, pegawai pemerintah, dan sebagainya.

Dinamika dan Tantangan Pancasila sangat berkaitan dengan dinamika kehidupan perjalanan masyarakat, bangsa Indonesia yang tidak bisa terlepas dari dinamika kehidupan yang bersifat internal maupun eksternal dari NKRI.

Hal itu dapat diketahui dari sejarah perjalanan Pancasila sebagai dasar negara, pandangan hidup bangsa, ideologi nasional, sumber dari segala sumber hukum negara yang diwarnai oleh berbagai konsepsi tentang bagaimana upaya guna mewujudkan cita - cita dan tujuan nasional, termasuk konsepsi yang digagas oleh penganut paham yang bukan berasaskan Pancasila. 
Oleh karena itu, sebagai ideologi terbuka dan konsep falsifikalisme, Pancasila selalu dihadapkan dengan adanya ancaman, gangguan, hambatan dan tantangan. Hanya keteguhan yang sungguh - sungguh dari setiap insan Indonesia yang dapat menjamin eksistensi Pancasila dapat lestari sepanjang masa.

Pendidikan Pancasila terutama bagi kalangan generasi muda (mahasiswa) merupakan sesuatu langkah yang sangat penting untuk dilakukan. Mengingat, mereka akan menjadi penentu keberhasilan dan perwujudan cita- cita Proklamasi 17 Agustus Tahun 1945. ditegaskan kembali bahwa secara historis, yang tampil sebagai pejuang dan pendiri Bangsa dan Negara ini, adalah kalangan generasi muda pada masanya.

Oleh karena itu, generasi muda saat ini harus tahu, mau dan mampu mewarisi nilai - nilai historis, bagaimana eksistensi generasi muda dalam mendirikan dan mengisi kemerdekaan NKRI termasuk melahirkan konsepsi Pancasila yang dimulai dari sidang BPUPKI 29 Mei - 1 Juni 1945, 22 Juni 1945, dan 18 Agustus 1945.

Perlu ditegaskan kembali bahwa secara Sosiologis, Pancasila merupakan tampilan sikap dan perilaku insan Indonesia dalam pergaulan sosial kemasyarakatan sehari-hari yang sekaligus menjadikannya sebagai karakter masyarakat bangsa Indonesia. Oleh karena itu, generasi muda sangat perlu untuk tetap memelihara perilaku sosial yang tetap berkarakter Pancasila, walaupun dinamika kehidupan sosial saat ini diwarnai oleh berbagai pengaruh dan penetrasi soaial budaya asing.

Era globalisasi tidak saja menghadirkan berbagai kemajuan dalam berbagai bidang yang dapat membantu mempermudah pekerjaan manusia, melainkan secara simultan menghadirkan berbagai ekses negatif yang tidak dapat diprediksi. Diperlukan kompetensi warga negara yang mampu menyikapi berbagai persoalan globalisasi tersebut secara bijaksana, baik kompetensi pengetahuan, sikap, dan keterampilan yang mumpuni, yang akan mampu menjawab berbagai persoalan globalisasi yang mengemuka.

Pancasila sebagai Ideologi dan Dasar Negara Indonesia merupakan pilihan ideologi yang sangat tepat yang mesti dijadikan rujukan utama bagi setiap warga negara dalam bertindak dalam konteks global. Hal ini tidak lain agar sikap dan perilaku yang ditampilkannya sesuai dengan nilai-nilai Pancasila. Dengan kata lain, sikap dan perilaku berkarakter Pancasila, yang terefleksikan dalam kehidupan sehari-hari.

Pancasila sebagai dasar negara, ideologi bangsa dan negara merupakan kekayaan bangsa yang tidak ternilai harganya bagi eksistensi dan kelangsungan hidup dan kehidupan bangsa Indonesia. Dapat dimaknai bahwa tidak ada Indonesia bila tidak ada Pancasila. Mengingat kedudukannya yang sangat penting dan strategis maka bangsa Indonesia perlu memposisikan Pancasila dalam wadah yang kuat, tegas, dan sah secara hukum.

Kesimpulan

Peranan Ideologi dalam kehidupan bermasyarakat, berbangsa, dan bernegara sebagaimana diuraikan, ideologi mengandung nilai-nilai dasar, norma-norma dan cita-cita yang ingin diwujudkan oleh masyarakat penganutnya. Karena itu, ideologi memiliki peranan sebagai 
dasar, arah, dan tujuan yang ingin dicapai dalam kehidupan bermasyarakat, berbangsa, dan bernegara.

Pancasila perlu disosialisasikan agar dipahami oleh dunia sebagai landasan filosofis bangsa Indonesia dalam mempertahankan eksistensi dan mengembangkan dirinya menjadi bangsa yang sejahtera dan modern. Sebagai ideologi nasional, ia harus diperjuangkan untuk diterima kebenarannya melewati batas-batas Negara bangsa kita sendiri.

\section{DAFTAR PUSTAKA}

Darmini Roza dan Laurensius Arliman S Peran Pemerintah Daerah Di Dalam Melindungi Hak

Anak Di Indonesia, Masalah-Masalah Hukum, Volume 47, Nomor 1, 2018.

Laurensius Arliman S, Komnas HAM dan Perlindungan Anak Pelaku Tindak Pidana, Deepublish, Yogyakarta, 2015.

Laurensius Arliman S, Penguatan Perlindungan Anak Dari Tindakan Human Trafficking Di Daerah Perbatasan Indonesia, Jurnal Selat, Volume 4, Nomor 1, 2016.

Laurensius Arliman S, Problematika Dan Solusi Pemenuhan Perlindungan Hak Anak Sebagai

Tersangka Tindak Pidana Di Satlantas Polresta Pariaman, Justicia Islamica, Volume 13, Nomor 2, 2016.

Laurensius Arliman S, Pelaksanaan Perlindungan Anak Yang Tereksploitasi Secara Ekonomi Oleh Pemerintah Kota Padang, Veritas et Justitia, Volume 2, Nomor 1, 2016.

Laurensius Arliman S, Kedudukan Ketetapan MPR Dalam Hierarki Peraturan PerundangUndangan Di Indonesia, Lex Jurnalica, Volume 13, Nomor 3, 2016.

Laurensius Arliman S, Komnas Perempuan Sebagai State Auxialiary Bodies Dalam Penegakan

Ham Perempuan Indonesia, Justicia Islamica, Volume 14, Nomor 2, 2017.

Laurensius Arliman S, Peranan Pers Untuk Mewujudkan Perlindungan Anak Berkelanjutan $D i$

Indonesia, Jurnal Ilmu Hukum Tambun Bungai, Volume 2, Nomor 2, 2017.

Laurensius Arliman S, Mewujudkan Penegakan Hukum Yang Baik Untuk Mewujudkan Indonesia

Sebagai Negara Hukum, Jurnal Hukum Doctrinal, Volume 2, Nomor 2, 2017.

Laurensius Arliman S, Participation Non-Governmental Organization In Protecting Child Rights

In The Area Of Social Conflict, The 1st Ushuluddin and Islamic Thought International Conference (Usicon), Volume 1, 2017.

Laurensius Arliman S, Partisipasi Masyarakat Dalam Pembentukan PerundangUndangan

Untuk

Mewujudkan Negara Kesejahteraan Indonesia, Jurnal Politik Pemerintahan Dharma

Praja, Volume 10, Nomor 1, 2017,

Laurensius Arliman S, Peran Komisi Perlindungan Anak Indonesia Untuk Mewujudkan

Perlindungan Anak, Jurnal Respublica Volume 17, Nomor 2, 2018.

Laurensius Arliman S, Menjerat Pelaku Penyuruh Pengrusakan Barang Milik Orang Lain

Dengan Mempertimbangkan Asas Fungsi Sosial, Jurnal Gagasan Hukum, Volume 1,

Nomor 1, 2019.

Laurensius Arliman S, Ilmu Perundang-Undangan Yang Baik Untuk Negara Indonesia, Deepublish, Yogyakarta, 2019.

Laurensius Arliman S, Isdal Veri, Gustiwarni, Elfitrayenti, Ade Sakurawati, Yasri, Pengaruh 
Karakteristik Individu, Perlindungan Hak Perempuan Terhadap Kualitas Pelayanan Komnas Perempuan Dengan Kompetensi Sumber Daya Manusia Sebagai Variabel Mediasi, Jurnal Menara Ekonomi: Penelitian dan Kajian Ilmiah Bidang Ekonomi, Volume 6, Nomor 2, 2020.

Laurensius Arliman S, Pendidikan Kewarganegaraan, Deepublish, Yogyakarta, 2020. Laurensius Arliman S, Makna Keuangan Negara Dalam Pasal Pasal 23 E Undang-Undang Dasar 1945, Jurnal Lex Librum, Volume 6, Nomor 2 Juni 2020, Laurensius Arliman S, Kedudukan Lembaga Negara Independen Di Indonesia Untuk Mencapai

Tujuan Negara Hukum, Kertha Semaya Journal Ilmu Hukum, Volume 8, Nomor 7, 2020. Laurensius Arliman S, Pelaksanaan Assesment Oleh Polres Kepulauan Mentawai Sebagai Bentuk Pelaksanaan Rehabilitasi Bagi Pecandu Dan Korban Penyalahgunaan Narkotika, Jurnal Muhakkamah, Volume 5, Nomor 1, 2020.

Laurensius Arliman S, Aswandi Aswandi, Firgi Nurdiansyah, Laxmy Defilah, Nova Sari Yudistia, Ni Putu Eka, Viona Putri, Zakia Zakia, Ernita Arief, Prinsip, Mekanisme Dan Bentuk Pelayanan Informasi Kepada Publik Oleh Direktorat Jenderal Pajak, Volume 17, No Nomor, 2020.

Larensius Arliman S, Koordinasi PT. Pegadaian (Persero) Dengan Direktorat Reserse Narkoba

Polda Sumbar Dalam Penimbangan Barang Bukti Penyalahgunaan Narkotika, UIR Law Review, Volume 4, Nomor 2, 2020, https://doi.org/10.25299/uirlrev.2020.vol4(1).3779. Laurensius Arliman S, Tantangan Pendidikan Kewarganegaraan Pada Revolusi 4.0, Ensiklopedia Sosial Review, Volume 2, Nomor 3, 2020.

Muhammad Afif dan Laurensius Arliman S, Protection Of Children's Rights Of The Islamic And

Constitutional Law Perspective Of The Republic Of Indonesia, Proceeding: Internasional Conference On Humanity, Law And Sharia (Ichlash), Volume 1, Nomor 2, 2020.

Otong Rosadi danLaurensius Arliman S, Urgensi Pengaturan Badan Pembinaan Idelogi Pancasila Berdasarkan Undang-Undang Sebagai State Auxiliary Bodies yang Merawat Pancasila dalam Perspektif Hak Asasi Manusia, Prosiding Konferensi Nasional Hak Asasi Manusia, Kebudayaan dan Tujuan Pembangunan Berkelanjutan Indonesia pada Masa Pandemi Covid-19: Tantangan untuk Keilmuan Hukum dan Sosial Volume 1, Universitas Pancasila, Jakarta, 2020. 